УДК 330.341:331.108:658.3

DOI: https://doi.org/10.37320/2415-3583/17.7

Маркіна I.A.

доктор економічних наук, професор

Полтавський державний аграрний університет ORCID: https://orcid.org/0000-0003-2815-4223

Вороніна В.Л.

кандидат економічних наук, доцент Полтавський державний аграрний університет ORCID: https://orcid.org/0000-0002-2434-4591

Філатова К.Є. здобувач

Полтавський державний аграрний університет

\title{
МЕНЕДЖМЕНТ ПЕРСОНАЛУ В УМОВАХ СТІЙКОГО ІННОВАЦІЙНОГО РОЗВИТКУ ПІДПРИЕМСТВА
}

\begin{abstract}
Метою статті є дослідження проблемних питань менеджменту персоналу в умовах стійкого інноваційного розвитку сучасних украӥнських підприємств. Актуальність теми дослідження підтверджується тим, що в інноваційній економіці, яка супроводжується безперервною трансформацією зовнішнього середовища $і$ зростанням невизначеності, однією з умов стійкого інновачійного розвитку підприємства є зростання його кадрового потениіалу. У статті проаналізовано особливості менеджменту розвитку персоналу в сучасних умовах інноваційних змін. Виявлено недоліки професійної підготовки та розвитку персоналу. Запропоновано підходи до поліпшення використання персоналу під час реалізації інновацій. Розглянуті у статті питання менеджменту розвитку персоналу забезпечують чітке уявлення про те, щзо головне місце в управлінні підприємством займає працівник, адже вся інноваційна діяльність спрямована на максимізацію прибутку та трунтується на задоволенні потреб персоналу підприємства.
\end{abstract}

Ключові слова: інноваційна діяльність, інноваційний розвиток, менеджмент, персонал, підприємство, управління.

Постановка проблеми. Об'єктивні соціально-економічні процеси, що відбуваються в умовах глобальних динамічних змін, змушують підприємства орієнтуватися на інноваційний розвиток. Забезпечення стійкого інноваційного розвитку сучасної організації зумовлює колосальну значимість інтелектуальних ресурсів організації, носієм яких передусім є персонал. Відповідно, питання стійкого інноваційного розвитку і питання управління персоналом, його компетенціями тісно взаємопов'язані.

Вітчизняні підприємства на практиці стикаються 3 проблемою неприйняття співробітниками інноваційної діяльності. Працівники чинять опір нововведенням, не бажають виявляти творчу спрямованість. Це призводить до низької результативності інноваційних дій, виконання яких перевищує фінансові та часові встановлені рамки.

Таким чином, у багатьох українських організаціях виявляється непідготовленість співробітників до певних змін. Джерело такої ситуації - використання в інноваційній діяльності тих самих методів управління, що й за звичайної функціональної діяльності.

Уважаємо, що вирішення виявленої проблеми полягає в усвідомленні безпосередньо керівником усієї значущості реформування підходів до управління інноваційною діяльністю, оскільки вона кардинально відрізняється від звичної такими факторами, як непередбачуваність, високий ступінь ризику, мінливість кінцевого результату в процесі роботи, важливість творчої спрямованості персоналу і володіння певними компетенціями.

Із метою опанування необхідних навичок та компетенцій, а також підвищення залучення співробітників до нововведень потрібно формувати й упроваджувати в компанію нові методи управління не лише діяльністю, а й персоналом [1].

Таким чином, в інноваційній економіці, що супроводжується безперервною трансформацією зовнішнього середовища і зростанням невизначеності, однією 3 умов стійкого інноваційного розвитку підприємства повинно стати якісне зростання його кадрового потенціалу, що здійснюється за допомогою реалізації ефективної системи управління.

Аналіз останніх досліджень і публікацій. Дослідженню проблем управління інноваційною діяльністю підприємства присвячено наукові праці вітчизняних та зарубіжних учених: І. Ансоффа, В. Бланка, С. Володіна, Л. Волощука, В. Вороніної, Н. Діденко, В. Захарченко, С. Ілляшенко, В. Катькало, О. Кузьміна, О. Мельника, П. Перерви, Б. Санто, Б. Твісса, С. Філіппової, Й. Шумпетера та ін.

Питання менеджменту персоналу підприємства в контексті інноваційного розвитку підприємства досліджували вчені: Л. Балабанова, В. Голянич, Н. Діденко, А. Єгоршин, I. Єпіфанова, М. Зось-Кіор, Н. Краснокутська, I. Маркіна, О. Овчарук, А. Орехова, Г. Тарасюк, О. Ястремська та ін.

Результати проведеного нами аналізу та узагальнення наукових напрацювань за темою дослідження свідчать про те, що практично відсутні фундаментальні комплексні роботи та, відповідно, є нагальна потреба в подальшому вдосконаленні теоретичних, методичних і практичних засад із проблематики менеджменту персоналу в умовах стійкого інноваційного розвитку підприємства. Зазначене зумовлює актуальність теми дослідження. 
Мета статті полягає у дослідженні проблемних питань менеджменту персоналу в умовах стійкого інноваційного розвитку сучасних українських підприємств.

Виклад основного матеріалу. Персонал $є$ ключовою стратегічною цінністю підприємства, основою його фінансово-економічного зростання за рахунок знань, інновацій та інформації, джерелом яких виступає людина.

Ефективний менеджмент персоналу розширює можливості підприємства, виводить його на новий конкурентний рівень, забезпечує стійкий інноваційний розвиток [2].

Система менеджменту персоналу в контексті інноваційного розвитку підприємства характеризується деякими особливостями, серед яких [9, с. 115]:

1) дефіцит інформаційного матеріалу за інноваційними проєктами;

2) новизна і трудомісткість функціонування членів робочої групи;

3) підвищена плинність наукових співробітників і фахівців;

4) висока ймовірність вилучення великих вигід у разі успіху.

Уважаємо, що існують певні умови, за яких управління персоналом у контексті інноваційного розвитку підприємства орієнтоване на довгострокову перспективу: інновації базуються на принципах, що кидають виклик традиційному управлінню; повинна бути системність інновацій, що включає велику кількість методів і процесів; інновації $є$ частиною безперервного процесу нововведень.

Будь-яке підприємство володіє певними індивідуальними особливостями, за допомогою яких може домогтися здійснення інноваційних ідей, задумів із подальшим отриманням вигоди від реалізації. Позитивний результат подібних дій найголовнішим чином залежить від співробітників підприємства, точніше від їх орієнтованості і сприйнятливості щодо нововведень. Тому, маючи на меті досягнення комерційного успіху від інноваційної діяльності, спочатку необхідно провести моніторинг готовності персоналу до незвичного їм функціонування [4].

Потрібно враховувати, що впровадження інновацій може бути сприйнято персоналом негативно, саме тому перш ніж уводити інновації, потрібно підготувати персонал до нововведень. На нашу думку, дані напрями знаходять своє відображення в таких управлінських рішеннях:

- збільшення рівня освіченості працівників: добре освічені співробітники легше піддаватимуться інноваціям, а також виступатимуть новаторами нових ідей;
- технологізація в управлінні і виробництві: надання технічних обладнань у вільному доступі;

- надання свободи персоналу у висловлюванні особистої думки про зміни, що проходять у відділі: проведення дискусій і консультацій із працівниками на тему нововведень;

- підтримання комунікації співробітників усіх підрозділів;

- надання можливості й заохочення персоналу в самостійності і творчих ініціативах;

- надання персоналу можливості для вивчення обсягів інформації для подальшого досягнення організаційних цілей.

Інноваційні організації, як правило, прагнуть формувати свої специфічні системи найму з метою відбору персоналу, який уже зацікавлений у роботі з нововведеннями. Така система відбору містить додаткові параметри, якими повинен володіти кандидат. Також ми вважаємо, що під час відбору доцільно використовувати якісну оцінку для виявлення творчої спрямованості особистості та їі здійснених ідей.

Важливо робити акцент не лише на залученні творчих людей, а й на розвитку і розкритті їхніх можливостей. Ми припускаємо, що із цією метою раціонально впровадити ротацію персоналу. Такий вид переміщення сприятиме як розвитку навичок, так і появі нових поглядів, свіжих ідей. Так, під впливом зміни оточення і виду діяльності працівник максимально активізується на розвиток, що благотворно позначається на результативності діяльності організації у цілому [8, с. 75$]$.

У ході дослідження встановлено, що підприємства, які схильні до інноваційної діяльності, застосовують у своїй роботі такі технології кадрового менеджменту:

- навчання наперед, яке необхідно для розвитку потенціалу працівників;

- достойна оплата праці працівників;

- залучення нових співробітників і утримання старих ефективних;

- планування і розвиток кар'єри співробітників в організації;

- система заохочень і підтримки персоналу для досягнення високого результату діяльності;

- обмін інформацією, необхідною для досягнення високих організаційних результатів;

- винагорода за ініціативність і самостійність співробітників.

Таблиця 1 - Інноваційні методи навчання персоналу

\begin{tabular}{|l|l|}
\hline \multicolumn{1}{|c|}{ Метод } & \multicolumn{1}{c|}{ Сутність } \\
\hline Візуалізація & $\begin{array}{l}\text { Може бути у двох формах: проєктивній і не проєктивній. Проєктивна форма візуалізації може представлятися } \\
\text { у вигляді відеороликів, фільмів, анімації, а не проєктивна -у вигляді предметів, дошки, картин }\end{array}$ \\
\hline Метод симуляції & $\begin{array}{l}\text { Даний метод може представлятися у вигляді ситуації, схожій із реальністю, тобто наближеною } \\
\text { до життєвих умов }\end{array}$ \\
\hline Метод кейса & $\begin{array}{l}\text { Полягає у тому, що являє собою опис конкретної ситуації, необхідно проаналізувати ситуацію, } \\
\text { їі результат, а також зробити висновки }\end{array}$ \\
\hline Рольова гра & Має на увазі закріплення отриманих знань за допомогою примірки учасниками різних ролей \\
\hline Воркшоп & $\begin{array}{l}\text { Є інтерактивним заходом, заснованим на активності учасників. Даний метод спрямований на самостійне } \\
\text { отримання знань учасниками в груповій взаємодії }\end{array}$ \\
\hline Тренінг & С практичним складником, представленим у формі практичних вправ із використанням невеликої частки теорії \\
\hline
\end{tabular}

Джерело: узагальнено авторами за [1; 3-5] 


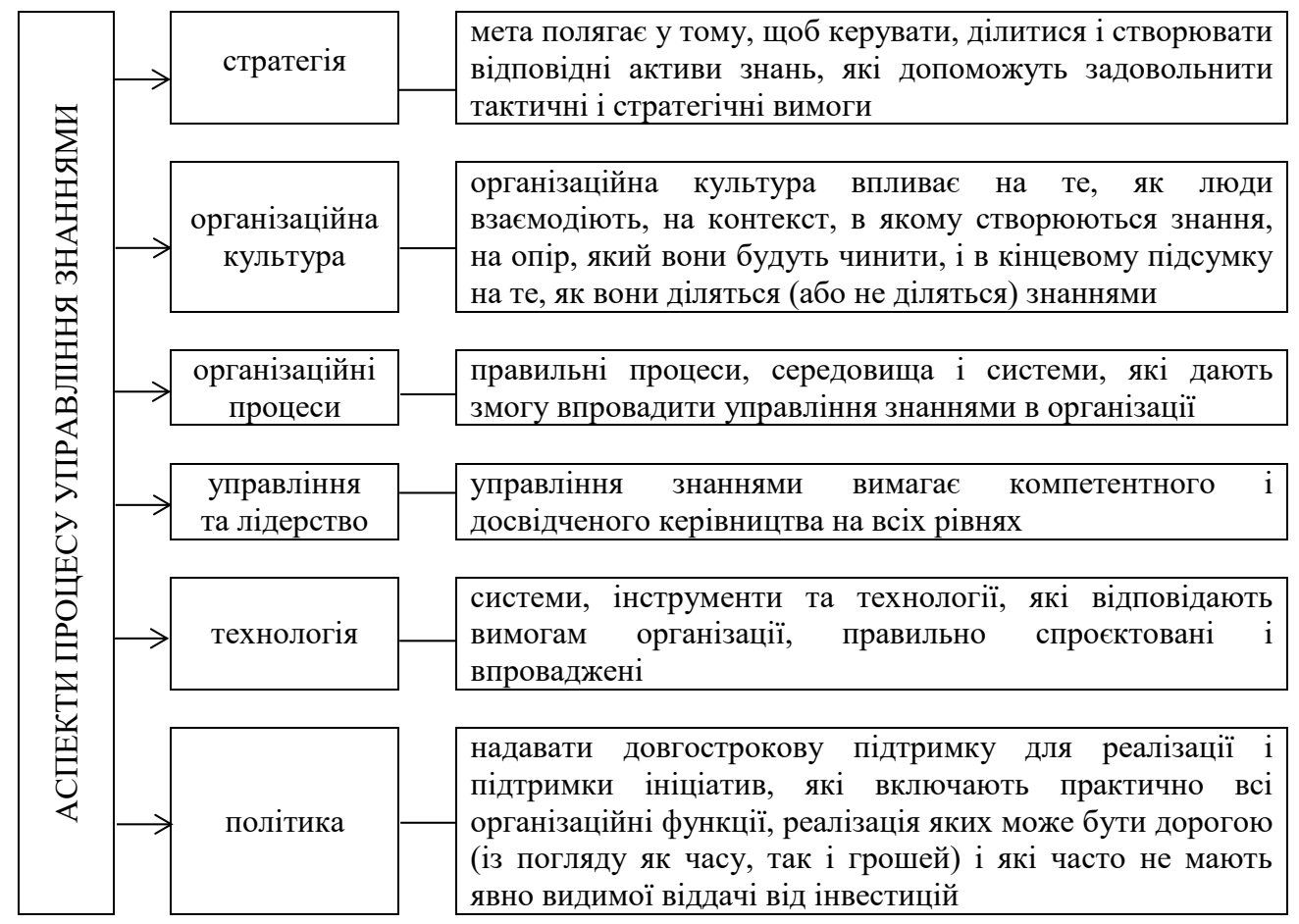

Рисунок 1 - Аспекти процесу управління знаннями

Джерело: узагальнено авторами за [3; 6; 9]

Одним зі значущих компонентів системи менеджменту персоналу в контексті інноваційного розвитку підприємства є стимулювання кадрового складу [3, с. 34].

Кожна організація по-своєму підходить до питання мотивації свого персоналу. Однак вітчизняні та зарубіжні підприємства щодо інструментів мотивації сходяться в такому [1]:

1) індивідуальна оцінка праці;

2) можливість навчання, підвищення кваліфікації;

3) розширення можливостей реалізації творчого потенціалу за допомогою професійної діяльності;

4) програми з обміну досвідом з іншими країнами;

5) вплив на прийняття рішення.

Як інноваційні методи навчання персоналу застосовуються методи, представлені в табл. 1 .

Розглянуті методи навчання передбачають, передусім, управління знаннями персоналу, що потребує створення нових знань або зосередження виключно на спільному використанні, зберіганні та уточненні знань [5].

Управління знаннями персоналу в контексті інноваційного розвитку підприємства - це створення цінності, використання й удосконалення активів знань підприємства для досягнення цілей інноваційної діяльності.

Аспекти процесу управління знаннями персоналу розглянуто на рис. 1.

Окрім цього, важливим аспектом, що необхідний для успішного інноваційного розвитку підприємства, є відношення до співробітників у колективі [10, с. 84]. Важко стимулювати людей до роботи за відсутності хороших, доброзичливих взаємин у колективі і бажань для впровадження якісних інновацій. Також не менш важливо аналізувати і тестувати працівників, щоб виділити схожі типи особистості й об'єднати співробітників в єдину згуртовану команду [7, с. 44]. Тільки з високим бажанням працювати, 3 комфортними умовами і надійними людьми поруч підприємство успішно функціонуватиме.

Висновки. Розглянуті у статті питання менеджменту розвитку персоналу забезпечують чітке уявлення про те, що головне місце в управлінні підприємством займає працівник, адже вся інноваційна діяльність спрямована на максимізацію прибутку та грунтується на задоволенні потреб персоналу підприємства.

\section{Список використаних джерел:}

1. Балабанова Л.В., Сардак О.В. Управління персоналом. URL: http://www.twirpx.com/file/544700/ (дата звернення: 11.03.2021).

2. Володін С.А., Чекамова О.І. Теоретичні засади формування і реалізації інноваційного потенціалу в розвитку економіки. Економіка АПК. 2017. № 5. С. 65-72. URL: http://nbuv.gov.ua/UJRN/E_apk_2017_5_12 (дата звернення: 28.03.2021).

3. Голянич В.М., Кудрявцева С.І. Інноваційні технології в кадровому менеджменті. Управлінське консультування. 2013. № 2(50). С. 34-48.

4. Діденко Н.В. Система антикризового менеджменту персоналу в сучасних умовах. URL: irbis-nbuv.gov.ua>cgi-bin/irbis_ nbuv/cgiirbis/ (дата звернення: 21.03.2021).

5. Егоршин А.П. Управління персоналом. Нижній Новгород, 2014. 198 с.

6. Ілляшенко В.В. Менеджмент. Москва : Академія, 2014. 235 с.

7. Максимов Н.Н. Теоретичні основи інноваційної діяльності. Молодий вчений. 2013. № 10. С. 43-51. 
8. Маркіна І.А., Вороніна В.Л., Хорошко Д.Р. Управління інноваційним потенціалом як фактор стратегічного розвитку та конкурентних переваг підприємства. Східна Європа: економіка, бізнес та управління. 2020. № 3(26). С. 76-81.

9. Пережогіна К.А. Інноваційні зміни в системі управління персоналом. Молодий вчений. 2015. № 4. С. 115-129.

10. Хмизова О.В., Сисан О.М. Напрями розвитку інноваційного потенціалу підприємства. Наукові праці. Економіка. 2016. T. 285. № 273. C. $83-88$.

\section{References:}

1. Balabanova L. V., Sardak O. V. Upravlinnia personalom [Personnel management]. Available at: http://www.twirpx.com/ file/544700/ (accessed 11 March 2021).

2. Volodin S. A., Chekamova O. I. (2017) Teoretychni zasady formuvannia i realizatsii innovatsiinoho potentsialu v rozvytku ekonomiky [Theoretical bases of formation and realization of innovative potential in development economy]. Ekonomika APK, no. 5, pp. 65-72. URL: http://nbuv.gov.ua/UJRN/E apk 20175 _ 12 (accessed 28 March 2021).

3. Holianych V. M., Kudriavtseva Ye. I. (2013) Innovatsiini tekhnolohii v kadrovomu menedzhmenti [Innovative technologies in personnel management]. Upravlinske konsultuvannia, no. 2(50), pp. 34-48.

4. Didenko N. V. Systema antykryzovoho menedzhmentu personalu v suchasnykh umovakh [The system of crisis management of personnel in modern conditions]. Available at: irbis-nbuv.gov.ua>cgi-bin/irbis_nbuv/cgiirbis/ (accessed 21 March 2021).

5. Ehorshyn A. P. (2014) Upravlinnia personalom [Personnel management]. N. Novhorod. (in Russian)

6. Iliashenko V. V. (2014) Menedzhment [Management]. Moscow. (in Russian)

7. Maksymov N. N. (2013) Teoretychni osnovy innovatsiinoi diialnosti [Theoretical foundations of innovation]. Molodyi vchenyi, no. 10 , pp. 43-51.

8. Markina I. A., Voronina V. L., Khoroshko D. R. (2020) Upravlinnia innovatsiinym potentsialom yak faktor stratehichnoho rozvytku ta konkurentnykh perevah pidpryiemstva [Management of innovation potential as a factor of strategic development and competitive advantages of the enterprise]. Skhidna Yevropa: ekonomika, biznes ta upravlinnia, no. 3(26), pp. 76-81.

9. Perezhohina K. A. (2015) Innovatsiini zminy v systemi upravlinnia personalom [Innovative changes in the personnel management system]. Molodyi vchenyi, no. 4, pp. 115-129.

10. Khmyzova O. V., Cysan O. M. (2016) Napriamy rozvytku innovatsiinoho potentsialu pidpryiemstva [Directions of development of innovative potential of the enterprise]. Naukovi pratsi. Ekonomika, vol. 285, no. 273, pp. 83-88.

Markina Iryna, Voronina Viktoriia, Filatova Kateryna Poltava State Agrarian University

\section{PERSONNEL MANAGEMENT IN CONDITIONS OF SUSTAINABLE INNOVATIVE DEVELOPMENT OF THE ENTERPRISE}

The purpose of the article is to study the problematic issues of personnel development management in the context of sustainable innovative development of modern Ukrainian enterprises. Enterprises are faced with the problem of employee rejection of innovative activities. Workers express resistance to innovation. They do not want to be creative. This results in low innovation performance. The authors of the article believe that the solution to the problem is the manager's awareness of the importance of reforming approaches to the management of innovative activities. It is necessary to form and implement new methods of personnel management in the company. It is necessary to master the necessary skills and competencies. The personnel is the main strategic value of the company. It is the basis for financial and economic growth. Effective personnel management expands the capabilities of the enterprise. Ensures its sustainable innovative development. It should be borne in mind that the introduction of an innovation can be perceived negatively by the staff. It is necessary to prepare staff for innovation and innovation. The features of the personnel management system in the context of the innovative development of the enterprise are considered. It is important to focus on the development and unleashing of staff capabilities. Rationally introduce personnel rotation. The review of technologies of personnel management of enterprises is carried out. An important component of the personnel management system in the context of the innovative development of the enterprise is the stimulation of the staff. Personnel knowledge management is the creation of value, use and improvement of enterprise knowledge assets to achieve the goals of innovation. The innovative methods of personnel training are considered. The disadvantages of professional training and development of personnel are identified.. It is important to analyze and test workers. To highlight similar personality types and unite employees into a single cohesive team. Approaches to improve the use of personnel in the implementation of innovations are proposed. The issues of personnel development management considered in the article provide a clear understanding of the important place of personnel in enterprise management. After all, innovative activity is aimed at maximizing profits and is based on meeting the needs of the company's personnel.

Key words: innovative activity, innovative development, management, personnel, enterprise.

JEL classification: D81, D83, M12, M54 